\title{
Understanding farmers' preferences for wastewater reuse frameworks in agricultural irrigation: lessons from a choice experiment in the Western Cape, South Africa
}

\author{
Cecilia Saldías ${ }^{1 *}$, Stijn Speelman', Guido van Huylenbroeck' and Nick Vink ${ }^{\mathbf{2}}$ \\ 'Department of Agricultural Economics, Ghent University, Coupure Links 653, 9000 Ghent, Belgium \\ ${ }^{2}$ Department of Agricultural Economics, Stellenbosch University, J.S. Marais Building, Private Bag X1, 7602 Stellenbosch, South Africa
}

\begin{abstract}
Wastewater has emerged as an alternative source of water. Since the agricultural sector remains the largest water user world-wide, it is the main potential user of treated wastewater. However, while there are trade-offs in using wastewater, it may be the only option in water-scarce regions. South Africa has included water reuse as a policy option; hence the aim of this study is to understand farmers' preferences regarding water reuse frameworks for irrigation. A choice modelling approach was applied to identify the elements defining these frameworks and to quantify their relative importance amongst farmers in the agricultural hinterland of Cape Town. The findings suggest that water reuse is acceptable to farmers in the area. Furthermore, they prefer options that guarantee good quality water and low levels of restrictions on use practices. Due to low trust in water service providers, farmers are willing to pay for a privately-managed scheme for water reuse, which suggests that the management model for implementing such schemes is important.
\end{abstract}

Keywords: water reuse, irrigation, agriculture, choice experiment, South Africa

\section{INTRODUCTION}

Wastewater has been recognised as an alternative source of water in water-scarce countries, especially for agriculture, which is the largest user and which has differentiated water quality requirements. For many water-scarce countries water reuse is the only affordable alternative (Lazarova et al., 2001). Unfortunately, there are trade-offs in using wastewater. Thus, to offset the potentially adverse effects of wastewater on public health and the environment, and to maximise the benefits from access to additional water, it is important to understand the framework within which, and the ground rules whereby, water reuse is to be implemented. This is possible from a study of the perceptions and preferences of water users. To this end, the purpose of this study was to identify the key elements required to develop a framework for water reuse based on the preferences of farmers, using a choice experiment (CE) approach, and to estimate their willingness-to-pay (WTP) for changes to this framework.

The analysis focused on the rural hinterland of Cape Town, South Africa, a water-scarce area whose agricultural sector is highly dependent on rainfall for both dryland and irrigation farming. Overall, water availability is the most important limiting factor for agricultural production in the country (NPC, 2012), a situation that will worsen due to the increasing demand for water from other sectors (Goldblatt, 2012). In this context, it becomes vital to search for alternative sources of water. Farmers in the study area already have some experience with water reuse, as some are already using treated wastewater (or treated effluent) from a municipal treatment plant to irrigate crops. It is envisaged that this case study can provide empirical grounds for assessing the acceptability of water reuse and offer lessons for policy formulation in a developing country context.

\footnotetext{
* To whom all correspondence should be addressed. e-mail: cecilia.saldiaszambrana@ugent.be

Received: 3 December 2014; accepted in revised from 13 November 2015
}

\section{The study site}

The hinterland of Cape Town in the Western Cape Province has a Mediterranean climate characterised by cool and wet winters (May-September) and warm, dry summers (OctoberFebruary). Although the average annual rainfall, which varies between 500 and $1500 \mathrm{~mm}$ across the area, is higher than the average for South Africa, it is a water-scarce region because of the rapidly growing urban population, the large water demand for irrigation, and the short run-off distances of surface water from the mountains to the sea.

In order to address equitable distribution and access to water, the Department of Water Affairs (DWA) (now the Department of Water and Sanitation (DWS)) has formulated the Western Cape Sustainable Water Management Plan to ensure that water is used efficiently across sectors, while exploring and implementing non-conventional sources such as desalination, use of deep aquifers, and water reuse (DWA, 2012).

Farmers in the study area grow wine grapes, deciduous fruit and vegetables under irrigation and also produce dryland grains (wheat, oats and canola). Production systems are adapted to the climatic and soil conditions as well as to water availability. The irrigation technology preferred is drip irrigation. Some farmers already use treated effluent from municipal wastewater treatment plants (WWTP) (e.g., from Potsdam WWTP near Cape Town, and from Malmesbury WWTP north of Cape Town) (Fig. 1). Overall, water use efficiency is high in this area (AgriPROBE, 2007).

The agricultural sector is strategically important both nationally and for the region. The direct contribution of agriculture to the gross domestic product (GDP) of the country is about $3 \%$, although, when the entire value chain is considered, its contribution is closer to $8 \%$ (Greyling, 2012). The province contributes some $23 \%$ of the value added by the sector to South Africa's GDP (the second highest after KwaZulu-Natal), but accounts for at least $60 \%$ of South Africa's agricultural exports, and is also a major employer of permanent and 


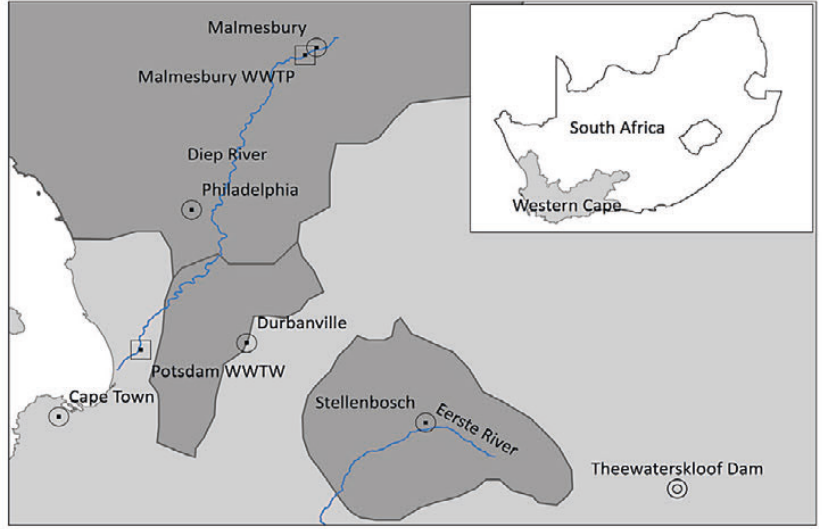

Figure 1

Location of the study area (schematic only)

seasonal workers (Murray, 2010). Considering the importance of this sector, water demand is expected to remain high. In this context, water reuse offers opportunities that need to be explored.

\section{METHODOLOGY}

Understanding consumer behaviour can lead to changes in service design, pricing strategy, and distribution channels, as well as concepts of public welfare (Louviere et al., 2000). For this study a choice modelling approach was adopted to foster understanding of farmers' preferences concerning frameworks of water reuse for irrigation. Choice modelling has gained recognition in the field of environmental valuation (Giergiczny and Kronenberg, 2014) and is increasingly applied to value water resources such as wetlands (e.g., Carlsson et al., 2003; Birol et al., 2006a; Milon and Scrogin, 2006) or water services (e.g., Snowball et al., 2008; Kanyoka et al., 2008). In relation to wastewater, in a study by Birol and Das (2010), choice modelling was used to estimate the local public's WTP for improvements in the capacity and technology of a sewage treatment plant in Chandernagore municipality in India. Another study by Genius et al. (2012) applied choice modelling to elicit the value of the attributes of a wastewater treatment plant in a rural area in Greece; the attributes included - among others - water quality and irrigation with recycled water. In contrast, Birol et al. (2008) applied the contingent valuation $(\mathrm{CV})$ method to investigate farmers' preferences for treated wastewater and their WTP; and Alcon et al. (2010) applied CV to estimate the non-market benefits derived from the use of reclaimed wastewater for agricultural purposes in Segura River Basin, Spain.

This study aims toward filling the knowledge gap to evaluate water reuse frameworks for irrigation, by applying a choice modelling approach. Choice modelling is grounded in the theory of value (Lancaster, 1966), which assumes that consumers' utility derived from goods can be decomposed into utilities from the constituent characteristics of these goods (Hanley et al., 2001; Louviere et al., 2008). Compared to CV, choice modelling has the potential to provide greater information about peoples' preferences. Thanks to the focus on the attributes, it can generate multiple value estimates from a single application, which is useful for decision-makers dealing with natural resource planning, both at the local and national level. As in CV, choice modelling can result in estimated economic values for any environmental resource, including nonuse and use values. Choice modelling also enables estimation of the implicit value of the attributes, their implied ranking and the value of changing more than one attribute at a time. Another advantage is that respondents are more familiar with the choice approach rather than the payment approach (Birol et al., 2006b). Choice modelling is also useful in the analysis of changes and trade-offs between attributes (Snowball et al., 2008).

A typical choice modelling exercise is composed of a number of stages, namely (i) selection of attributes, (ii) assignment of levels, (iii) choice experimental design, (iv) construction of choice sets, (v) measurement of preferences, and (vi) estimation procedure (Hanley et al., 2001). These stages are addressed in the following sub-sections.

\section{Selection of attributes and assignment of levels}

In CEs, respondents are asked to choose among different alternative specifications of a good. These are described in terms of the attributes of the good and the levels that these attributes take. In this case, the good to be valued is the framework for water reuse in irrigation. In order to select appropriate attributes of the good, it is important to understand the characteristics of the study site in terms of water management, agricultural production, and policies and regulations governing water and wastewater. In the case of this research, 4 attributes were identified, based on a literature review and on expert interviews: 'water quantity-quality', 'practice restrictions', 'management model' (of the scheme) and 'price'.

The attribute 'water quantity-quality' refers to the access to different quantities of water and the relative water quality standards available. Four levels were proposed:

- A1 (limited water quantity - up to $50 \mathrm{~m}^{3} / \mathrm{day}$, strict quality standards and reduced nutrient content)

- A2 (limited water quantity - up to $50 \mathrm{~m}^{3} /$ day, general quality standards and high nutrient content)

- A3 (maximum water quantity - up to $2000 \mathrm{~m}^{3} /$ day, general quality standards and high nutrient content)

- A4 (unlimited water quantity, quality standards less strict than the general standards and high nutrient content)

Note that there are trade-offs between quantity and quality. The volumes of water specified for these levels were based on information contained in the Government Gazette (RSA, 2013).

The second attribute, the 'practice restrictions' refers to the measures to be taken while using the water to irrigate. Three levels were identified for this attribute, namely:

- High: strict restriction on irrigation of crops for human consumption (e.g., vegetables eaten raw not allowed); strict control over irrigation methods (implies periodic inspections); and strict monitoring of water use (e.g., protective measures, including the use of protective clothes, signalling of water pipes and reservoirs, waiting periods between irrigation and harvesting, avoiding direct contact between water and crops, use of drip irrigation)

- Moderate: irrigation of crops for human consumption which are not eaten raw is allowed, including fruit trees and vineyards; moderate control over irrigation methods (implies sporadic inspections); and regular monitoring of water use (e.g., protective measures)

- Low: no restriction on crops; no restriction of irrigation methods; regular monitoring of water use (e.g., protective measures) 
The third attribute refers to the proposed 'management model' for the scheme. This refers to models for water supply infrastructure and management. Three levels were proposed:

- Public: financed, operated and managed by a public agency, e.g., the municipality

- Private: financed, operated and managed by the users; wastewater is pre-treated at the municipality; monitoring of water quality standards remains under the DWS

- Public-private-partnerships: funding is shared, e.g., users contribute to capital costs for development of the infrastructure, tariffs take into account maintenance and operating costs only, management is by the users, the municipality is only involved in delivering the water to a certain point in the scheme

Finally, price was included as one of the attributes to enable estimation of the WTP for changes in other attribute levels, with the following levels: 5, 2.5 and $1 \mathrm{ZAR} / \mathrm{m}^{3}$. Appendix A, Table 1A presents the attributes and their respective levels.

\section{Choice experimental design and construction of choice sets}

The experimental design consisted of selecting a set of choices from the set of all possible choice sets, which comply with specific statistical properties such as identification and precision, and with non-statistical properties such as realism and complexity (Louviere et al., 2000). For this analysis, we constructed a generic CE using the software JMP 11.2.0. This implies that the alternatives/profiles were unlabelled. A full factorial design produced a total of 108 profiles $\left(4^{1} \times 3^{3}\right)$. However, this was still a large number to evaluate. To address this issue a fractional design maximising $\mathrm{D}$-efficiency was constructed. This design had D-efficiency of $95 \%$, A-efficiency of $89 \%$ and G-efficiency of $69 \%$. These indicators specify the goodness of the design relative to the hypothetical design.

Next, the profiles were grouped into 12 choice sets and divided into 3 blocks to be presented to the respondents: each respondent had to consider 4 choice sets. An opt-out option was also included. This was preferred over the status quo option because there was no common status quo for the respondents, with some currently using treated wastewater and some not. The choice sets were presented in pictograms in order to decrease the cognitive burden of the exercise (Speelman and Veettil, 2013). An example of a choice set is provided in Appendix B, including the pictogram used.

\section{Data collection process}

The process of data collection consisted of a survey in the study area between April and July 2014. The CE was part of this survey, which also included questions on socio-economic characteristics, cropping patterns, irrigation practices and perceptions on wastewater reuse. The respondents were randomly selected and the language of communication was English. The sample size was linked to the experimental design. In JMP 11.2.0, a minimum sample size of 45 respondents necessary to generate an efficient design - with a D-efficiency of a desired level - was set. With this sample size 184 observations were generated for the choice modelling exercise. Seventeen (17) of the respondents are part of a group of 43 farmers that currently use treated wastewater for irrigation (38 in Durbanville and 5 in Malmesbury). This represents about $40 \%$ of the total number of farmers using treated wastewater in the area. The remaining 29 respondents were included as a control group. Overall the sample size represents about $6 \%$ of the population of 795 farming units in Bellville/ Durbanville, Stellenbosch and Malmesbury (Statistics South Africa, 2006).

\section{Model specification}

The last step in the CE consists of the estimation procedure, which was done in 2 steps: first a conditional logit model (CL) was estimated and then a latent class model (LC).

The theoretical foundation of choice modelling is the random utility theory (McFadden, 1974), which suggests that individuals make choices based on the characteristics of the good along with a random component which may result from the uniqueness of preferences of the individual or from the analyst's incomplete information about the individual. The utility $U_{i j}$ of an individual $i$ derived from an alternative $j$ is decomposed into an observable component $V_{i j}$ and an unobserved random component $\varepsilon_{i j}$ :

$$
U_{i j}=V_{i j}+\varepsilon_{i j}
$$

$V_{\mathrm{ij}}$ can be expressed as a linear function of the explanatory variables as follows:

$$
V_{i j}=x_{i j}^{\prime} \beta
$$

where: $\beta$ is a vector of coefficients associated with the vector $x^{\prime}$ of explanatory variables, which are attributes of alternative $j$, including the socioeconomic factors of individual $i$ (Snowball et al., 2008). The underlying assumption is that individual $i$ would choose alternative $j$ over alternative $k$, if $U_{i j}>U_{i k}$ (McFadden, 1974).

Considering that the explanatory variables are attributes, a CL was applied in this study. This model is suitable when the choice among alternatives is modelled as a function of the attributes of the alternatives rather than (or in addition to) the attributes of the respondent. Compared to the Multinomial Logit model, CL models the problems of interest by using a 'characteristics of the alternative' approach. In a CL, it is assumed that the error of disturbances has a Type 1 extreme value distribution: $\exp \left[-\exp \left(-\varepsilon_{i j}\right)\right]$. The selection of an alternative is expressed as (McFadden, 1974):

$$
U_{i j}>\max _{k} €_{c i, k \neq j} U_{i k}
$$

The probability of choosing an alternative $j$ among $n$ choices for individual $i$ is given by:

$$
P_{i}(j)=P\left[x_{i j}^{\prime} \beta+\varepsilon_{i j} \geq \max _{k} \epsilon_{c i}\left(x_{i k}^{\prime} \beta+\varepsilon_{i k}\right)\right]=\frac{\exp \left(x_{i j}^{\prime} \beta\right)}{\sum_{k} \epsilon_{c i} \exp \left(x_{i k}^{\prime} \beta\right)}
$$

The parameters of the CL were estimated applying the maximum likelihood estimation procedure using the software NLOGIT 5.0.

A disadvantage of the CL, however, is that it assumes homogeneity in preference across respondents, as one single parameter estimate is generated for each choice attribute (Colombo et al., 2009). To solve this, a LC model was applied in a second step. This model accounts for heterogeneity in the systematic part of utility, but differs in the assumptions about the distribution of preferences (Sagebiel, 2011). The model can capture variations in preferences between segments of respondents (Birol et al., 2006a). Usually it outperforms models that assume homogeneity of preferences (Provencher and Bishop, 
2004; Birol et al., 2006a; Sagebiel, 2011). Compared to a random parameters logit (RPL) model, which also incorporates heterogeneity in the analysis, a LC model is superior for welfare measures and interpretation (Birol et al., 2006a). Sagebiel (2011) compared RPL and LC, and found that the LC has a slight statistical advantage over the RLP. He suggested that LC should be chosen when different groups within the sample are expected, which show within-class homogeneity (Sagebiel, 2011).

In the LC model, heterogeneity in preferences is included through the observable component. Assuming the existence of $s$ segments in a population and that individual $i$ belongs to segment $s(s=1, \ldots, S)$, the utility function can be expressed as follows (Greene and Hensher, 2003):

$$
U_{i j \mid s}=x_{i j}^{\prime} \beta_{s}+\varepsilon_{i j \mid s}
$$

The probability of choice for an individual $i$, considering that the individual belongs to segment $s$, of selecting an alternative $j$ in the $t^{\text {th }}$ choice set of $n$ alternatives, for a particular choice activity is given by:

$$
P_{i j t \mid s}=\left|\frac{\exp \left(\beta_{s} x_{i j t}^{\prime}\right)}{\sum_{j=1}^{J} \exp \left(\beta_{s} x_{\text {int }}^{\prime}\right)}\right|
$$

Then, the probability that an individual belongs to a particular segment is given in Eq. 7, where $Z_{\mathrm{i}}$ is a vector of individual-specific variables and $a_{\mathrm{s}}$ is a vector of segment-specific parameters to be estimated:

$$
P_{i s}=\left|\frac{\exp \left(a_{s}^{\prime} z_{i}\right)}{\sum_{s=1}^{S} \exp \left(a_{s}^{\prime} z_{i}\right)}\right|
$$

The probability that any randomly selected respondent chooses an alternative is obtained combining the conditional probability (Eq. 6) with the segment membership probability (Eq. 7) as follows:

$$
P_{i j}=\sum_{s=1}^{s}\left(\frac{\exp \left(a_{s}^{\prime} z_{i}\right)}{\sum_{s=1}^{s} \exp \left(a_{s}^{\prime} z_{i}\right)}\right) \Pi_{t}^{T}=1\left(\frac{\exp \left(\beta_{s} x_{\mathrm{ijt}}^{\prime}\right)}{\sum_{j=1}^{J} \exp \left(\beta_{s} x_{\mathrm{int}}^{\prime}\right)}\right)
$$

The parameters for the LC model were estimated by applying the maximum likelihood estimation procedure in the software NLOGIT 5.0. Given the sample size, the model was run for 2 segments only. The goodness-of-fit of the model was measured by the likelihood ratio index (LRI). Well-fitted models take LRI values larger than 0.2 (Hoyos, 2010); in our model the LRI is 0.26 (see Table 2A in Appendix A).

For the segment membership function, different combinations of variables were tested. This was a trial-and-error procedure until robust results were found. The combination of variables that generated results included: the perception of health threats from irrigation with treated effluent, the perception of environmental threats, and the current use of treated effluent (see Table 2).

\section{WTP estimation}

In choice modelling, it is possible to estimate WTP by including price as an attribute of the good (Hanley et al., 2001). The marginal utility estimates (coefficients) can be transformed into estimates for changes in attribute levels. By combining different attribute changes, welfare measures can be obtained (Hoyos, 2010). WTP for changes in attribute levels or the marginal rate of substitution (MRS) is done by taking the ratio between the coefficients of individual attributes and the price attribute (Speelman and Veettil, 2013):

$$
\mathrm{WTP}=\frac{\beta_{k}}{-\beta m}
$$

$\beta_{k}$ is the attribute's coefficient and $-\beta_{m}$ is the price attribute coefficient. WTP values for attribute changes and $95 \%$ confidence intervals were estimated through the use of the Wald Procedure (Delta Method) in the software NLOGIT 5.0.

\section{RESULTS AND DISCUSSION}

\section{Socio-economic and farm characteristics}

Most farmers are white males and $79.5 \%$ are full-time farmers. Their level of education is high: $75 \%$ have a tertiary degree (either university or postgraduate), and their average monthly household income is estimated at about ZAR 38397 (median = ZAR 30 000). Farms are also relatively large in terms of cultivated area: for instance, the average size of land cultivated with grapes is 78.1 ha (max. 500 ha; min. 10 ha); with fruit trees is 15.7 ha ( $\max .30$ ha; $\min .4$ ha); and with grains is 330.9 ha (max. 1600 ha; min. 30 ha). Given the high level of education, it was expected that farmers are aware of the issues of water scarcity and water pollution, and how this can affect agricultural production.

About a third of the respondents grew only wine grapes, while $46.7 \%$ grew wine grapes in combination with other crops, e.g., olive trees, fruit trees or grains, while some $20 \%$ grew a combination of crops that did not include grapes. The dominance of wine grapes in the area dates back to the $17^{\text {th }}$ Century (Ponte and Ewert, 2009), so that when respondents were asked if they would shift to other crops if more water was available, only $32.6 \%$ answered 'yes'.

Most farmers stored rainfall runoff to supply their water for irrigation; some $37 \%$ currently use treated effluent as a source for irrigation. Some had access to water from the Theewaterskloof dam, and a few to water from boreholes. When respondents were asked if they had experienced water scarcity in the past 5 years, $41.3 \%$ responded affirmatively, ostensibly because the cropping pattern is clearly adapted to the current availability of water. Similarly, the technology used for irrigation is efficient, which decreases the amount of water wasted. Finally, the rainfall pattern varies across the peninsula and its hinterland, so there might be some areas which in effect do not experience severe water shortages, while others are naturally drier. Overall, those that access water from Theewaterskloof were satisfied. Water conflicts were not reported as a major issue in the area, with only $10.9 \%$ of respondents indicating that they had experienced water-related conflicts in the past 5 years.

In Appendix A, Table $3 \mathrm{~A}$ shows the demographic characteristics of the farmers.

\section{Farmers' perceptions on the use of treated wastewater}

More than half of the respondents indicated that they would use treated effluent for irrigation in the future, but only $15 \%$ were willing to give up their current entitlements in exchange 
for access to treated effluent (see Table 3A in Appendix A). This was not unexpected, considering that securing water is one of the determinants of success in agricultural production.

In Table 1, the farmers' perceptions about the use of treated wastewater are presented for the whole sample and for the segments generated by the LC. The results indicate that respondents disagreed that irrigation with treated effluent is a threat to the health of farmers or workers; to the health of the consumers (this result is significantly different between the segments); or to the environment. Similar results were reported by Adewumi et al. (2010), who found that the perception of risks associated with water reuse was low among respondents in a survey conducted in the City of Cape Town. Jovanovic (2008) found that - despite some concerns about poor quality water and its effects on soils, crop yields, human health and the environment, farmers in the Bottelary catchment in the Western Cape were willing to use treated effluent for irrigation. This positive perception is important considering that acceptance has been identified as the main obstacle to the implementation of water reuse projects (Po et al., 2003). In this case, it might be associated with high awareness of water scarcity. Adewumi et al. (2010) indicated that conserving drinking water and mitigating the effects of water shortages are the main drivers of water reuse in the City of Cape Town. Jovanovic (2008) suggested that, compared to other water sources, treated effluent has a relative cost advantage.

On average, respondents were indifferent towards the statement that irrigation with treated effluent can damage the soils or can pollute groundwater. In the former statement, however, there is a significant difference between the segments. One reason why respondents in Segment 2 tend to disagree might be linked to the fact that more farmers in this segment currently use treated effluent compared to Segment 1; therefore, they advocated for this practice and they did not want to reveal possible negative effects on the soil. However, it has been demonstrated that extended use of treated effluent can increase electrical conductivity and sodium content in soils (Castro et al., 2011). Additionally, it can have consequences for groundwater, resulting in potential contamination with faecal coliforms and parasite ova (El Lateef et al., 2006). More information on this aspect is required for the area.

A similar answer was obtained when farmers were asked about the prospects for reducing quantities of nutrients to be applied to the soil. Although there are potential benefits from nutrients contained in wastewater (Durán-Álvarez and Jiménez-Cisneros, 2014), respondents on average did not seem

\begin{tabular}{|c|c|c|c|c|c|}
\hline \multicolumn{6}{|c|}{$\begin{array}{c}\text { TABLE } 1 \\
\text { Respondents' perceptions }\end{array}$} \\
\hline Perceptions on the use of treated effluent (average score) ${ }^{(a)}$ & $\begin{array}{c}\text { Mean } \\
\text { (Std. Dev.) }\end{array}$ & Min. & Max. & $\begin{array}{c}\text { Seg.1 } \\
(n=26)\end{array}$ & $\begin{array}{c}\text { Seg.2 } \\
(n=20)\end{array}$ \\
\hline \multicolumn{6}{|l|}{ Irrigation with treated effluent: } \\
\hline is a threat to the health of farmers and workers & $3.9(0.90)$ & 1 & 5 & $3.62(0.98)$ & $4.25(0.64)$ \\
\hline is a threat to the health of consumers of the produce ${ }^{\star *}$ & $3.8(1.02)$ & 1 & 5 & $3.46(1.10)$ & $4.30(0.66)$ \\
\hline is a threat to the environment & $3.9(0.89)$ & 2 & 5 & $3.58(0.86)$ & $4.35(0.75)$ \\
\hline can damage the soils ${ }^{* * *}$ & $3.2(1.04)$ & 1 & 5 & $2.96(0.82)$ & $3.45(1.23)$ \\
\hline can pollute groundwater & $3.3(1.07)$ & 1 & 5 & $2.92(0.89)$ & $3.75(1.12)$ \\
\hline enhances agricultural production & $2.5(1.03)$ & 1 & 5 & $2.81(0.80)$ & $2.15(1.18)$ \\
\hline reduces the quantities of nutrients to be applied in the soil & $2.9(1.06)$ & 1 & 5 & $2.62(0.98)$ & $3.25(1.07)$ \\
\hline should be encouraged by the authorities & $1.7(0.86)$ & 1 & 4 & $1.69(0.88)$ & $1.80(0.83)$ \\
\hline Treated effluent is an alternative source to fight water scarcity & $1.5(0.62)$ & 1 & 4 & $1.62(0.70)$ & $1.45(0.51)$ \\
\hline Regulations for reuse of treated effluent in agriculture are poor ${ }^{(b)}$ & $3.2(1.01)$ & 1 & 5 & $3.00(0.96)$ & $3.40(1.05)$ \\
\hline $\begin{array}{l}\text { Regulations for reuse of treated effluent in agriculture are comprehensive } \\
\text { and encourage reuse }{ }^{(b)}\end{array}$ & $2.9(1.00)$ & 2 & 5 & $3.08(0.91)$ & $2.70(1.08)$ \\
\hline $\begin{array}{l}\text { Water quality standards for agricultural use of treated effluent are poor } \\
\text { and put public health and the environment at risk }\end{array}$ & $3.7(0.97)$ & 1 & 5 & $3.48(1.01)$ & $3.95(0.89)$ \\
\hline $\begin{array}{l}\text { Water quality standards for agricultural use of treated effluent are too } \\
\text { stringent to comply with }\end{array}$ & $3.6(0.86)$ & 1 & 5 & $3.64(0.81)$ & $3.60(0.94)$ \\
\hline $\begin{array}{l}\text { Institutions responsible for implementing reuse of treated effluent are not } \\
\text { supportive }^{(b)}\end{array}$ & $2.7(0.94)$ & 1 & 4 & $2.72(0.94)$ & $2.75(0.97)$ \\
\hline $\begin{array}{l}\text { Infrastructure required to convey treated effluent to fields is too costly, } \\
\text { which impedes the use of treated effluent for agricultural irrigation }{ }^{(b)}\end{array}$ & $2.8(1.00)$ & 1 & 4 & $2.60(1.00)$ & $3.00(0.97)$ \\
\hline $\begin{array}{l}\text { Process of registration of water use licenses, permits or authorisations for } \\
\text { treated effluent, is too bureaucratic and discouraging }{ }^{(b)}\end{array}$ & $2.6(1.17)$ & 1 & 4 & $2.68(1.18)$ & $2.55(1.19)$ \\
\hline $\begin{array}{l}\text { Authorities don't support the use of treated effluent in agricultural irriga- } \\
\text { tion; as a consequence there aren't enough incentives to take this option }{ }^{(b)}\end{array}$ & $2.7(0.97)$ & 1 & 4 & $2.80(0.91)$ & $2.55(1.05)$ \\
\hline
\end{tabular}

The $t$-tests and Pearson chi-square tests show significant differences at $\left.{ }^{*}\right) 10 \%,\left({ }^{* *}\right) 5 \%$ and $\left(^{* * *}\right) 1 \%$ level.

(a) Treated as continuous variables with the following scale for reference: $1=$ strongly agree; $2=$ agree; $3=$ neither; $4=$ disagree; $5=$ strongly disagree

(b) For segment 1 the $\mathrm{n}^{\circ}$ of respondents is $\mathrm{n}=25$ (one respondent did not answer). 
to perceive this as entirely beneficial. On the other hand, the average respondent agreed that irrigation with treated effluent should be encouraged and that it is an alternative water source.

Furthermore, respondents did not seem to have a clear position on regulations for reuse of treated effluent in agriculture. However, they considered that water quality standards were sufficient to protect public health and the environment, and not too stringent to comply with, even though national guidelines do not really exist (these results might not be significant due to the small difference in answers between the segments and in some cases due to the sample size). The 'South African guide for the permissible utilisation and disposal of treated effluent' (DNHPD, 1978 cited by Adewumi et al., 2010) promotes the concept of 'no potential risk' to public health when using wastewater. Adewumi et al. (2010) argued that under this guideline expensive technology and processes are required, rendering the water unaffordable for developing communities.

Respondents' perception concerning institutional support for implementing reuse of treated effluent was again indistinct, probably because of a lack of communication between institutions and water users (UBC EnvCom, undated). Furthermore, the costs of water conveyance were not seen as an impediment to the use of treated effluent in agricultural irrigation. This is contrary to what Adewumi et al. (2010) found for water reuse in Cape Town. They found that as distance from the treated wastewater source increased, fewer respondents were willing to use treated effluent because the capital cost of laying pipelines was considered to be significant. The opinion of farmers on this matter is important, given that funding remains an obstacle to wider use of treated wastewater (Bixio et al., 2006). In most countries, reuse schemes are still largely subsidised (Hochstrat et al., 2007) as distortions still exist in water supply markets (Bixio et al., 2006). Adewumi et al. (2010) did, however, find that if the tariff for treated effluent was lower than for drinking water, more respondents indicated willingness to reuse wastewater in Cape Town.

\section{Preferences for frameworks of water reuse}

The data were first analysed by means of a CL model. However, since possible variations in preferences that could result from heterogeneity amongst respondents were of interest, the data were also analysed by means of a LC model. Since this model proved to be superior (i.e., LRI $=0.26$ ), only these results are discussed in more detail.

The segments in the model were balanced. Segment 1 held $54.4 \%$ of the respondents, whereas Segment 2 held $45.6 \%$. The 'current use of treated effluent' was what differentiated the two segments most: $80 \%$ of respondents in Segment 2 currently already use treated effluent versus 3.85\% in Segment 1. This difference was significant at the $1 \%$ level (see Table $4 \mathrm{~A}$ in Appendix A), but as 'segmenting variable' in the LC model this variable was not statistically significant (see Table 2). Respondents who are currently using treated effluent were

\begin{tabular}{|c|c|c|c|}
\hline \multicolumn{4}{|c|}{$\begin{array}{c}\text { TABLE } 2 \\
\text { Results of the CL and LC models, and WTP estimates }\end{array}$} \\
\hline & \multirow[t]{2}{*}{$\mathrm{CL}$} & \multicolumn{2}{|c|}{ LC } \\
\hline & & Segment 1 & Segment 2 \\
\hline A1 & $0.187(0.274)$ & $1.096^{*}(0.658)$ & $-0.328(0.585)$ \\
\hline A2 & $-0.440(0.275)$ & $-0.141(0.563)$ & $-0.684(0.431)$ \\
\hline A3 & $0.211(0.286)$ & $-1.075(0.875)$ & $0.954(0.898)$ \\
\hline High practice restrictions & $-1.099^{* * *}(0.304)$ & $-1.934^{\star \star}(0.853)$ & $-1.159^{\star}(0.680)$ \\
\hline Moderate practice restrictions & $-0.209(0.258)$ & $0.248(0.652)$ & $-0.799(0.690)$ \\
\hline Private scheme model & $0.169(0.202)$ & $-0.474(0.346)$ & $0.995^{\star \star}(0.459)$ \\
\hline Private-public partnership scheme model & $0.041(0.224)$ & $-0.407(0.383)$ & $0.641(0.493)$ \\
\hline Price & $-0.423^{* * *}(0.08)$ & $-0.629^{* *}(0.262)$ & $-0.421^{* * *}(0.125)$ \\
\hline \multicolumn{4}{|l|}{ Model statistics } \\
\hline Pseudo $\rho^{2}$ & 0.152 & 0.26 & \\
\hline Log likelihood & -170.82 & -149.91 & \\
\hline \multicolumn{4}{|c|}{ Segment function LC: respondents' perceptions on irrigation with treated effluent } \\
\hline \multicolumn{2}{|l|}{ Constant } & $8.050(5.423)$ & \\
\hline \multicolumn{2}{|c|}{$\begin{array}{l}\text { Irrigation with treated effluent is a threat to the health of farmers } \\
\text { and workers }{ }^{(a)}\end{array}$} & $-1.068(2.364)$ & \\
\hline \multicolumn{2}{|c|}{ Irrigation with treated effluent is a threat to the environment ${ }^{(b)}$} & $-0.555(1.611)$ & \\
\hline \multicolumn{2}{|l|}{ Use of treated effluent } & $-4.701(3.671)$ & \\
\hline \multicolumn{4}{|c|}{ WTP for changes in attribute levels and $95 \%$ confidence intervals } \\
\hline \multicolumn{2}{|l|}{ High practice restrictions } & $-3.07^{* * *}(-4.46 ;-1.69)$ & $-2.76^{*}(-5.92 ; 0.41)$ \\
\hline \multicolumn{2}{|l|}{ Private scheme model } & $-0.75(-1.95 ; 0.45)$ & $2.37^{\star}(-0.38 ; 5.11)$ \\
\hline
\end{tabular}

Significance at $\left(^{*}\right) 10 \%$; $\left(^{* *}\right) 5 \%$ and $\left({ }^{* *}\right) 1 \%$ level.

(a) Dummy variable on the perception of irrigation with treated effluent in relation to health of farmers/workers

(b) Dummy variable on the perception of irrigation with treated effluent in relation to the environment

Note: Only significant WTP estimates are reported, in ZAR/m³. 
motivated mainly by water scarcity and access to a municipal WWTP. Other socio-economic (e.g., age, income, educational level) or perceptions variables (e.g., irrigation with treated effluent is a threat to the health of farmers and workers; or irrigation with treated effluent is a threat to the environment) were not statistically significant.

Respondents in both segments presented similar socio-economic characteristics (see Table 4A in Appendix A). However, more respondents in Segment 1 grew only grapes (about 15 percentage points more) while more respondents grew a combination of grapes and other crops (about 24 percentage points more) in Segment 2. For other crops the difference between segments is about 9 percentage points. In Segment 2, respondents were more inclined to shift to other crops if water was accessible (about 22 percentage points more).

In terms of the 'water quantity-quality' attribute, respondents in Segment 1 preferred the alternative with limited water quantity, strict quality standards and reduced nutrient content over the reference level with unlimited water quantity, quality standards less strict than the general standards and high nutrient content. The latter was selected as the reference level because it described a less stringent scenario in terms of water quantity and quality. In contrast, other levels became more stringent. This preference was not found in Segment 2. Familiarity with the practice of reuse of treated effluent suggests that farmers in Segment 2 were less inclined to choose strict quality standards. 'High practice restrictions', which implies strict restriction on crops to be cultivated, strict control over irrigation methods and strict monitoring, was not favoured by the respondents in either of the segments.

Respondents in Segment 2 preferred a 'private scheme model' compared to a 'public scheme'; this result is significant. In contrast, for Segment 1 this coefficient is not statistically significant. In this regard, while there is on-going debate about the public versus private management of water and sanitation provision (e.g., Budds and McGranahan, 2003; Smith, 2004), the public sector still seems to struggle to deliver optimal services in developing countries because of lack of accountability, corruption, poor financial capacity, and inability to expand and upgrade water services in a reliable and cost-effective way (McDonald and Ruiters, 2005). South Africa has not escaped these effects, as attested by widespread public protests against the quality of public service delivery (Mpehle, 2012). Furthermore, Mpehle (2012: 213) argued that service delivery in South Africa has been negatively affected by aspects such the 'deployment of unskilled, unqualified and inexperienced cadres to municipal management positions, the accumulation of wealth by a few individuals through the abuse of the tendering system, inadequate revenue due to centralisation of funding, and absence of proper systems of collecting revenue by municipalities'.

Finally, both segments expressed a negative preference for an increase in the price attribute. These results are expected under the assumption that a price increase reduces preferences for alternatives. Notwithstanding, a higher price is less preferred in Segment 1, ostensibly because respondents in Segment 2 currently use treated effluent for which they already pay.

\section{WTP for changes}

Mean WTP for a change from 'high-practice-restrictions' to 'low-practice-restrictions' is estimated at ZAR 3.07 and ZAR 2.76 per $\mathrm{m}^{3}$ for Segment 1 and Segment 2, respectively. Both values are statically significant. Furthermore, for Segment 2, the mean WTP for a 'private scheme model' is estimated at ZAR 2.37 per $\mathrm{m}^{3}$ (this estimate is not statistically significant for Segment 1). Only significant results are reported in Table 2.

Interestingly, farmers value fewer restrictions on the selection of crops, application of irrigation methods and monitoring of water use if they are to irrigate with treated effluent. This can be understood from two perspectives. First, it is assumed that wastewater has undergone treatment, which produces treated effluent of acceptable quality and therefore can be applied to crops. Similarly, for the type of irrigation method applied, there is no real problem as farmers generally use drip irrigation. Second, since agriculture is export oriented, they are already subjected to wide-ranging food quality and safety regulations.

Another significant finding is that the type of management model seems to matter. In this case, a private scheme is valued in Segment 2. This is aligned with expectations, as some farmers expressed their mistrust in public institutions, and with the assumption that users may prefer a private scheme based on the reliability of the service. A previous study on WTP for multiple-use water services suggested that in rural South Africa there is room for the adoption of cost-recovery mechanisms, provided that the water services proposed respond to the needs of users (Kanyoka et al., 2008). The WTP for a private scheme for water reuse suggests that users are prepared to contribute to cost recovery. Nevertheless, more research is needed on this aspect.

\section{CONCLUSIONS}

This article contributes to the literature in two respects. First, important elements that have to be considered in frameworks for water reuse in agriculture were identified. Second, farmers' preferences for these frameworks were explored through choice modelling. To the best of our knowledge, this kind of study has not been done before; therefore this is a contribution to the literature on economic valuation of the use of wastewater for irrigation.

Generally, farmers in the rural hinterland of Cape Town have a positive perception of water reuse for irrigation, largely because they are aware of the problem of water scarcity. This is important since public perceptions and acceptance of water reuse are recognised as the main components of success for any reuse project. Furthermore, one of the segments showed that strict water quality standards are preferred despite the concomitant limitations on water quantity. It implies that farmers will irrigate crops with treated effluent if 'good-quality water' is guaranteed. Although, on average, the respondents disagreed that irrigation with treated effluent was a threat to the health of farmers and workers, or to the health of consumers, guaranteeing water quality was their main concern, apparently because agriculture in the area is export-oriented.

Another interesting finding was that farmers who already made use of treated wastewater preferred a privately managed scheme over a public scheme. This is in line with the utilitarian standpoint, which suggests that water users are expected to value private services based on the reliability of the water service (see Vásquez, 2011). Trust in the authorities to provide safely-treated effluent has already been identified as a fundamental issue in determining public acceptance of water reuse (Po et al., 2003). A study in Australia indicated that trust in the service provision agency was the main reason why people were willing to use wastewater (Kaercher et al., 2003). In the Western Cape, farmers are willing to pay for a privately-managed scheme, probably because of a lack of trust in the service 
provision agency. This is in line with the findings of Adewumi et al. (2010), who reported that poor trust in the service provider for treated effluent was probably influenced by the poor quality of treated effluent supplied over time. This suggests that the type of scheme for reuse of water is important.

Finally, when using treated effluent, there are implications for public health, which is one reason why people were discouraged from choosing this option. However, in this study, the WTP for a change from 'high-practice-restrictions' to 'lowpractice-restrictions' may reflect farmers' dislike of strict regulations for agricultural practices. This may negatively influence users' willingness to opt for this option. Although regulations and guidelines should protect public health and allow for safe reuse of water, they should, at the same time, take into account the local cultural and socioeconomic conditions (Mizyed, 2013). We agree with Mizyed (2013) on the need for regular reviews of the implementation, applicability and acceptance of quality standards for water reuse, taking into consideration the dynamics of a changing society.

\section{ACKNOWLEDGEMENTS}

The study was funded by the International Water Management Institute and Ghent University. The authors thank Dr Barbara van Koppen, IWMI-South Africa, for her comments and encouragement; the Department of Agricultural Economics, Stellenbosch University, for the support and collaboration during fieldwork; and Mrs Taryn Allie, Mr Steward Knott and Mr Kevin Andrews - your support in the logistics was appreciated. Special thanks to the respondents and interviewees who generously shared their views on this topic. We sincerely thank two anonymous reviewers for their comments and suggestions on an earlier version of this paper.

\section{REFERENCES}

ADEWUMI JR, ILEMOBADE AA and VAN ZYL JE (2010) Treated wastewater reuse in South Africa: Overview, potential and challenges. Resour. Conserv. Recy. 55 (2) 221-231. http://dx.doi. org/10.1016/j.resconrec.2010.09.012

AGRIPROBE (2007) Satellite images show water use efficiency. URL: http://www.waterwatch.nl/fileadmin/bestanden/Project/Africa/ grapes/AgriProbe_2007_4_3.pdf (Accessed 15 October 2014).

ALCON F, PEDRERO F, MARTIN-ORTEGA J, ARCAS N, ALARCON JJ and DE MIGUEL MD (2010) The non-market value of reclaimed wastewater for use in agriculture: a contingent valuation approach. Span. J. Agric. Res. 8 (S2) S187-S196. http://dx.doi.org/10.5424/ sjar/201008s2-1361

BIROL E, KAROUSAKIS K and KOUNDOURI P (2006a) Using a choice experiment to account for preference heterogeneity in wetland attributes: The case of Cheimaditida wetland in Greece. Ecol. Econ. 60 (1) 145-156. http://dx.doi.org/10.1016/j. ecolecon.2006.06.002

BIROL E, KAROUSAKIS K and KOUNDOURI P (2006b) Using economic valuation techniques to inform water resources management: A survey and critical appraisal of available techniques and an application. Sci. Total Environ. 365 (1-3) 105-122. http://dx.doi. org/10.1016/j.scitotenv.2006.02.032

BIROL E, KOUNDOURI P and KOUNTOURIS Y (2008) Evaluating farmers' preferences for wastewater: quantity and quality aspects. Int. J. Water 4 (1-2) 69-86. http://dx.doi.org/10.1504/IJW.2008.018148

BIROL E and DAS S (2010) Estimating the value of improved wastewater treatment: The case of River Ganga, India. J. Environ. Manage. 91 (11) 2163-2171. http://dx.doi.org/10.1016/j.jenvman.2010.05.008

BIXIO D, THOEYE C, DE KONING J, JOKSIMOVIC D, SAVIC D, WINTGENS T and MELIN T (2006) Wastewater reuse in
Europe. Desalination 187 (1-3) 89-101. http://dx.doi.org/10.1016/j. desal.2005.04.070

BUDDS J and MCGRANAHAN G (2003) Are the debates on water privatization missing the point? Experiences from Africa, Asia and Latin America. Environ. Urbanization 15 (2) 87-114. http://dx.doi. org/10.1177/095624780301500222

CARLSSON F, FRYKBLOM P and LILJENSTOLPE C (2003) Valuing wetland attributes: an application of choice experiments. Ecol. Econ. 47 (1) 95-103. http://dx.doi.org/10.1016/j. ecolecon.2002.09.003

CASTRO E, MAÑAS MP and DE LAS HERAS J (2011) Effects of wastewater irrigation on soil properties and turfgrass growth. Water Sci. Technol. 63 (8) 1678-1688. http://dx.doi.org/10.2166/ wst.2011.335

COLOMBO S, HANLEY N and LOUVIERE J (2009) Modelling preference heterogeneity in stated choice data: an analysis for public goods generated by agriculture. Agric. Econ. 40 (3) 307-322. http:// dx.doi.org/10.1111/j.1574-0862.2009.00377.x

DURÁN-ÁLVAREZ JC and JIMÉNEZ-CISNEROS B (2014) Beneficial and negative impacts on soil by the reuse of treated/untreated municipal wastewater for agricultural irrigation: A review of the current knowledge and future perspectives. In: Hernandez Soriano MC (ed.) Environmental Risk Assessment of Soil Contamination. Intech, Open Science, Croatia. http://dx.doi.org/10.5772/57086

DWA (DEPARTMENT OF WATER AFFAIRS, SOUTH AFRICA (2012) Western Cape Sustainable Water Management Plan 2012 Part 1, The Water Plan. URL: http://eadp.westerncape.gov.za/sites/ default/files/news/files/2012-12-05/sustainable-water-managementplan-approved-by-MEC-Bredell-13-06-2012.pdf (Accessed 20 October 2014).

EL LATEEF EMA, HALL JE, LAWRENCE PC and NEGM MS (2006) Cairo-East Bank effluent re-use study 3 - Effect of field crop irrigation with secondary treated wastewater on biological and chemical properties of soil and groundwater. Biomed. Life Sci. Biologia 61 (19) S240-S245. http://dx.doi.org/10.2478/s11756-006-0165-y

GIERGICZNY M and KRONENBERG J (2014) From valuation to governance: Using choice experiment to value street trees. Ambio 43 (4) 492-501. http://dx.doi.org/10.1007/s13280-014-0516-9

GENIUS M, MENEGAKI AN and TSAGARAKIS KP (2012) Assessing preferences for wastewater treatment in a rural area using choice experiments. Water Resour. Res. 48 (4) W04501. DOI:10.1029/2011WR010727. http://dx.doi. org/10.1029/2011WR010727

GOLDBLATT A (2012) Agriculture: Facts \& Trends, South Africa. URL: http://awsassets.wwf.org.za/downloads/facts_brochure_ mockup_04_b.pdf (Accessed 13 July 2015).

GREENE W and HENSHER D (2003) A latent class model for discrete choice analysis: contrasts with mixed logit. Transport. Res. Part B: Method. 37 (8) 681-698. http://dx.doi.org/10.1016/ S0191-2615(02)00046-2

GREYLING JC (2012) The role of the agricultural sector in the South African economy. Masters thesis (unpublished), Stellenbosch University.

HANLEY N, MOURATO S and WRIGHT R (2001) choice modelling Approaches: a superior alternative for environmental valuation? J. Econ. Surv. 15 (3) 435-462. http://dx.doi. org/10.1111/1467-6419.00145

HOCHSTRAT R, JOKSIMOVIC D, WINTGENS T, MELIN T and SAVIC D (2007) Economic considerations and decision support tool for wastewater reuse scheme planning. Water Sci. Technol. 56 (5) 175-182. http://dx.doi.org/10.2166/wst.2007.570

HOYOS D (2010) The state of the art of environmental valuation with discrete choice experiments. Ecol. Econ. 69 (8) 1595-1603. http:// dx.doi.org/10.1016/j.ecolecon.2010.04.011

JMP (11.2.0) [computer software] URL: http://www.jmp.com/software/jmp/.

JOVANOVIC NZ (2008) The use of treated effluent for agricultural irrigation: current status in the Bottelary catchment (South Africa). In: Villacampa Esteve Y, Brebbia CA and Prats Rico D (eds) Proceedings of the Second International Conference on Sustainable Irrigation Management, Technologies and Policies, 11-13 June 2008, Alicante. http://dx.doi.org/10.2495/SI080361 
KAERCHER JD, PO M and NANCARROW BE (2003) Water recycling community discussion meeting I (unpublished manuscript). Australian Research Centre for Water in Society (ARCWIS), Perth.

KANYOKA P, FAROLFI S and MORARDET S (2008) Households' preferences and willingness to pay for multiple use water services in rural areas of South Africa: An analysis based on choice modelling. Water SA 34 (6) 715-723.

LANCASTER K (1966) A new approach to consumer theory. J. Polit. Econ. 74 (2) 132-157. http://dx.doi.org/10.1086/259131

LAZAROVA V, LEVINE B, SACK J, CIRELLI G, JEFFREY P, MUNTAU H, SALGOT M and BRISSAUD F (2001) Role of water reuse for enhancing integrated water management in Europe and Mediterranean countries. Water Sci. Technol. 43 (10) 25-33.

LOUVIERE JJ, HENSHER DA and SWAIT JD (2000) Stated Choice Methods: Analysis and Applications. Cambridge University Press, Cambridge, New York, Melbourne. 420 pp.

LOUVIERE JJ, ISLAM T, WASI N, STREET D and BURGESS L (2008) Designing discrete choice experiments: Do optimal designs come at a price? J. Cons. Res. 35 (2) 360-375. http://dx.doi. org/10.1086/586913

McDONALD DA and RUITERS G (2005) Theorizing water privatization in Southern Africa. In: McDonald DA and Ruiters G (eds) The Age of Commodity: Water Privatization in Southern Africa. Earthscan, UK, USA.

McFADDEN D (1974) Conditional logit analysis of qualitative choice behaviour. In: Zarembka P (ed.) Frontiers in Econometrics. Academic Press, New York.

MILON JW and SCROGIN D (2006) Latent preferences and valuation of wetland ecosystem restoration. Ecol. Econ. 56 (2) 162-175. http:// dx.doi.org/10.1016/j.ecolecon.2005.01.009

MIZYED NR (2013) Challenges to treated wastewater reuse in arid and semi-arid areas. Environ. Sci. Polic. 25 186-195. http://dx.doi. org/10.1016/j.envsci.2012.10.016

MPEHLE Z (2012) Are service delivery protests justifiable in the democratic South Africa? J. Publ. Admin. 47 (1.1) 213-227.

MURRAY M (2010) Key trends in the agricultural economy of the Cape Winelands District Municipality: Implications for farm workers and dwellers. URL: http://www.phuhlisani.com/oid\%5C downloads\%5C20100619CWDMAgricTrendsV04f\%20edited.pdf (Accessed 06 July 2015).

NLOGIT (5.0) [computer software] URL: https://www.limdep.com/ products/nlogit/.

NPC (2012) Our Future: Make it Work. National Development Plan 2030. National Planning Commission, Pretoria.
PO M, KAERCHER JD and NANCARROW BE (2003) Literature review of factors influencing public perceptions of water reuse. Report to Australian Urban Water Conservation and Reuse Research Program. URL: http://www.clw.csiro.au/publications/ technical2003/tr54-03.pdf (Accessed 23 October 2014).

PONTE S and EWERT J (2009) Which way is "up" in upgrading? Trajectories of change in the value chain for South African wine. World Dev. 37 (10) 1637-1650. http://dx.doi.org/10.1016/j. worlddev.2009.03.008

PROVENCHER B and BISHOP RC (2004) Does accounting for preference heterogeneity improve the forecasting of a random utility model? A case study. J. Environ. Econ. Manage. 48 (1) 793-810. http://dx.doi.org/10.1016/j.jeem.2003.11.001

RSA (REPUBLIC OF SOUTH AFRICA) (2013) Government Notice $N^{\circ} 665$, Department of Water Affairs: Revision of General Authorisations in terms of Section 39 of the National Water Act, 1998. Pretoria. Government Gazette, 6 September 2013. URL: http:// faolex.fao.org/docs/pdf/saf126916.pdf (Accessed 30 April 2014).

SAGEBIEL J (2011) Comparing the latent class model with the random parameters logit: A choice experiment analysis of highly heterogeneous electricity consumers in Hyderabad, India. Department for Agricultural Economics, Humboldt-Universitat zu Berlin.

SNOWBALL JD, WILLIS KG and JEURISSEN C (2008) Willingness to pay for water service improvements in middle-income urban households in South Africa: A stated choice analysis. S. Afr. J. Econ. 76 (4) 705-720. http://dx.doi.org/10.1111/j.1813-6982.2008.00209.x

SPEELMAN S and VEETTIL CP (2013) Heterogeneous preferences for water rights reforms among smallholder irrigators in South Africa. Bio-based Appl. Econ. 2 (2) 131-149.

SMITH L (2004) The murky waters of the second wave of neoliberalism: Corporatization as a service delivery model in Cape Town. Geoforum 35 (3) 375-393. http://dx.doi.org/10.1016/j. geoforum.2003.05.003

STATISTICS SOUTH AFRICA (2006) Census of Agriculture Provincial Statistics 2002-Western Cape: Financial and Production Statistics. Report N¹1-02-02. Statistics South Africa, Pretoria.

UBC ENVCOM (UNION OF THE BALTIC CITIES COMMISSION ON ENVIRONMENT) (undated) Involvement and Communication. URL: http://ec.europa.eu/environment/life/project/Projects/index. $\mathrm{cfm}$ ?fuseaction=home.showFile\&rep=file\&fil=CHAMP_guide_7.pdf (Accessed 23 October 2014).

VÁSQUEZ WF (2011) Household preferences and governance of water services: A hedonic analysis from rural Guatemala. IFPRI, Development Strategy and Governance Division, Discussion Paper 01152. IFPRI, Washington, DC. 


\begin{tabular}{|l|c|c|c|c|}
\hline \multicolumn{3}{|c|}{ Attributes and levels for choice sets } \\
\hline Attributes & \multicolumn{3}{c|}{ Levels } \\
\hline Water quantity, quality \& nutrient content & A1 & A2 & A3 \\
\hline Practice restrictions & High & Moderate & Low \\
\hline Scheme model & Private & $\begin{array}{c}\text { Private-Public } \\
\text { Partnership }\end{array}$ & Public \\
\hline Price (in ZAR $\left./ \mathrm{m}^{3}\right)^{*}$ & 5 & 2.5 & 1 \\
\hline
\end{tabular}

${ }^{\star}$ USD $1=$ ZAR 10.5

\section{TABLE 2A}

Criteria to determine optimal number of segments

\begin{tabular}{|l|c|c|c|c|}
\hline $\mathbf{N}^{\circ}$ segments & Log likelihood & LRI $\left(\boldsymbol{\rho}^{\mathbf{2}}\right)$ & AIC & 1.944 \\
\hline 1 & -170.82 & 0.15 & 1.847 & 2.083 \\
\hline 2 & -149.91 & 0.26 & 2.196 \\
\hline
\end{tabular}

Source: criteria from Speelman and Veettil (2013).

\begin{tabular}{|c|c|c|c|}
\hline \multicolumn{4}{|c|}{$\begin{array}{c}\text { TABLE } 3 A \\
\text { Descriptive statistics of the sample }\end{array}$} \\
\hline & $\begin{array}{c}\text { Mean } \\
\text { (Std Dev.) }\end{array}$ & Min. & Max. \\
\hline Gender (\% male) & 91.3 & & \\
\hline Household size (number) & $3.22(1.37)$ & 1 & 7 \\
\hline Dependent children (number) & $1.60(1.09)$ & 0 & 4 \\
\hline Household income (ZAR/month) & $38397(22375)$ & 4500 & 100000 \\
\hline \multicolumn{4}{|l|}{ Education (\%) } \\
\hline Higher & 75.6 & & \\
\hline Basic & 24.4 & & \\
\hline Occupation (\% full time farmer) & 79.5 & & \\
\hline \multicolumn{4}{|l|}{ Crops cultivated (\%) } \\
\hline Grapes & 33.3 & & \\
\hline Grapes \& others & 46.7 & & \\
\hline Other crops & 20.0 & & \\
\hline Would shift to other crops if water is accessible (\% yes) & 32.6 & & \\
\hline Currently using treated effluent for irrigation (\%) & 37.0 & & \\
\hline Water scarcity in past 5 years (\% did experience) & 41.3 & & \\
\hline Water conflicts in past 5 years (\% did experience) & 10.9 & & \\
\hline Willing to exchange water entitlements for treated effluent (\% yes) & 15.0 & & \\
\hline Would use treated effluent in the future (\% yes) & 69.0 & & \\
\hline
\end{tabular}




\begin{tabular}{|c|c|c|}
\hline \multicolumn{3}{|c|}{$\begin{array}{c}\text { TABLE 4A } \\
\text { Profile of the segments }\end{array}$} \\
\hline & $\begin{array}{c}\text { Seg.1 } \\
(n=26)\end{array}$ & $\begin{array}{c}\text { Seg.2 } \\
(n=20)\end{array}$ \\
\hline Gender (\% male) & 92.31 & 90.00 \\
\hline Household size (number) $^{(\mathrm{a})}$ & $2.96(1.22)$ & $3.59(1.50)$ \\
\hline Dependent children (number) ${ }^{(b)}$ & $1.50(1.00)$ & $1.73(1.22)$ \\
\hline Household income (ZAR/month) & $41381(24440)$ & $33577(18453)$ \\
\hline \multicolumn{3}{|l|}{ Education (\%) ${ }^{(c)}$} \\
\hline Higher & 73.08 & 78.95 \\
\hline Basic & 26.92 & 21.05 \\
\hline Occupation (\% full time farmer) ${ }^{(\mathrm{d})}$ & 80.77 & 77.78 \\
\hline \multicolumn{3}{|l|}{ Crops cultivated (\%) ${ }^{(e)}$} \\
\hline Grapes & 40.00 & 25.00 \\
\hline Grapes \& others & 36.00 & 60.00 \\
\hline Other crops & 24.00 & 15.00 \\
\hline Would shift to other crops if water is accessible (\% yes) & 23.08 & 45.00 \\
\hline Currently using treated effluent for irrigation ${ }^{* * *}(\%)$ & 3.85 & 80.00 \\
\hline Water scarcity in past 5 years (\% did experience) & 42.31 & 40.00 \\
\hline Water conflicts in past 5 years (\% did experience) & 11.54 & 10.00 \\
\hline Willing to exchange water entitlements for treated effluent (\% yes) ${ }^{(\mathrm{f})}$ & 16.00 & 13.33 \\
\hline Would use treated effluent in the future (\% yes) & - & - \\
\hline
\end{tabular}

Note: For frequencies only valid percent is reported. The $t$-tests and Pearson chi-square tests show significant differences at $\left({ }^{*}\right) 10 \%$; $\left(^{* *}\right) 5 \%$ and (***) $1 \%$ level.

(a) For segment 1 the $n^{\circ}$ of respondents is $n=23$; for segment 2 is $n=17$

(b) For segment 1 the $n^{\circ}$ of respondents is $n=20$; for segment 2 is $n=15$

(c) For segment 2 the $n^{\circ}$ of respondents is $n=19$

(d) For segment 2 the $n^{\circ}$ of respondents is $n=18$

(e) For segment 1 the $n^{\circ}$ of respondents is $n=25$

(f) For segment 1 the $n^{\circ}$ of respondents is $n=25$; for segment 2 is $n=15$.

\section{APPENDIX B}

Example of a choice set:

\begin{tabular}{|l|l|l|l|}
\hline B1-3 & Alternative 1 & Alternative 2 & Alternative 3 \\
\hline Water quantity & Up to $50 \mathrm{~m}^{3} /$ day & Unlimited quantity & Up to $2000 \mathrm{~m}^{3} /$ day \\
\hline Water quality & $\begin{array}{l}\text { General quality } \\
\text { standards }\end{array}$ & $\begin{array}{l}\text { Less than General } \\
\text { Standards }\end{array}$ & $\begin{array}{l}\text { General quality } \\
\text { standards }\end{array}$ \\
\hline Nutrient content & High & High & High \\
\hline Practice restrictions & Low & High & Moderate \\
\hline Scheme model & $\begin{array}{l}\text { Public Private } \\
\text { Partnership }\end{array}$ & Private & Public \\
\hline Price & $5 \mathrm{ZAR} / \mathrm{m}^{3}$ & $2.5 \mathrm{ZAR} / \mathrm{m}^{3}$ & $2.5 \mathrm{ZAR} / \mathrm{m}^{3}$ \\
\hline
\end{tabular}

Which alternative do you prefer?

None of these alternatives:
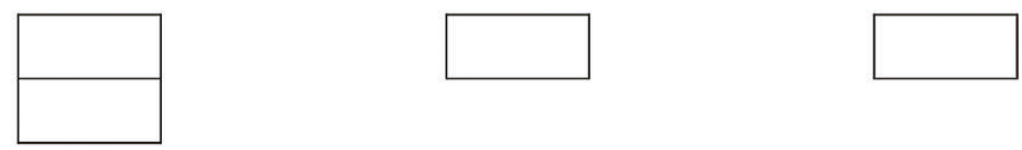
APPENDIX B (cont'd)

Example of a choice set in pictograms:

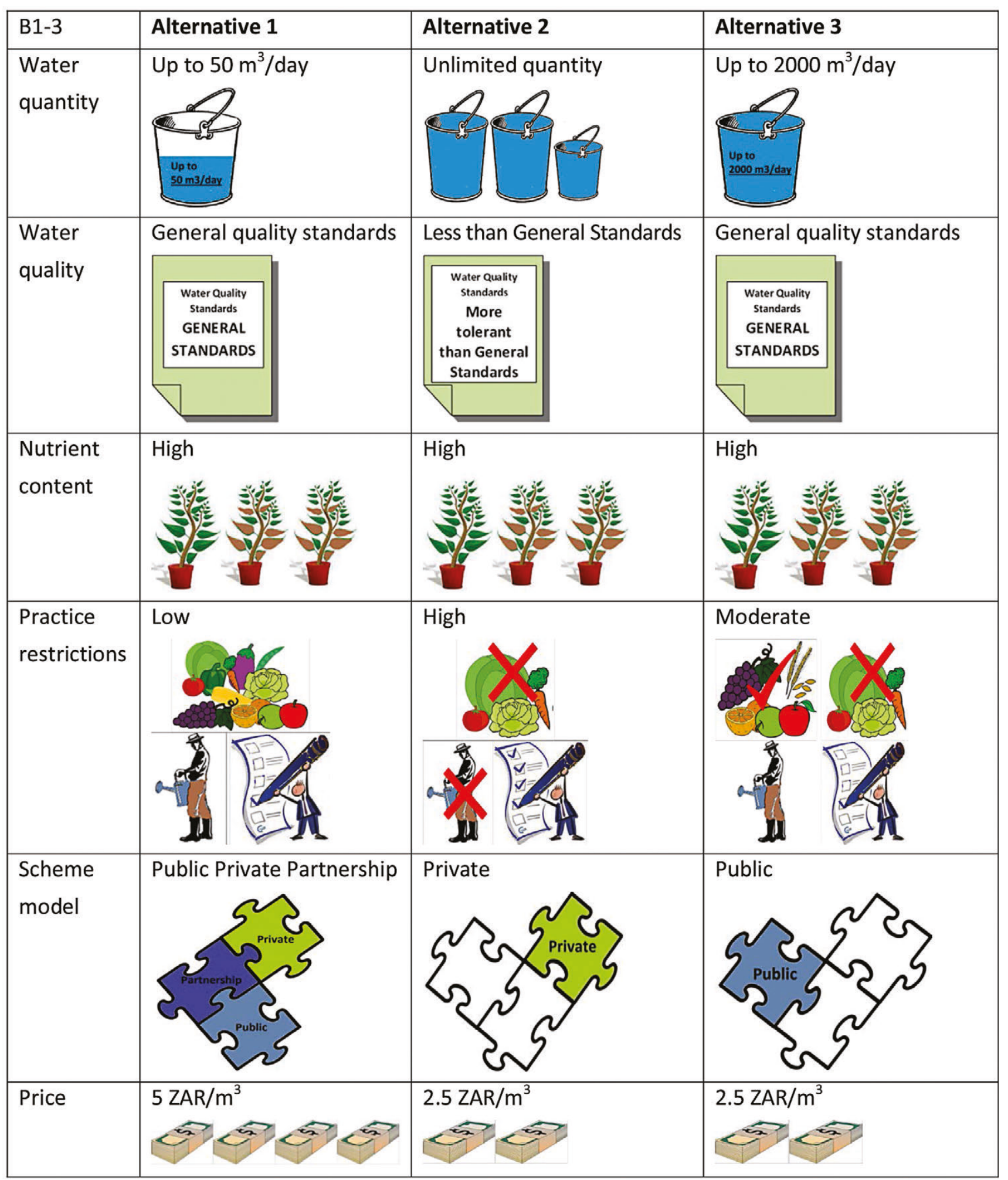

